Bangladesh J. Genet Pl. Breed., 21(1): 29-34, 2008

\title{
COMBINING ABILITY FOR QUANTITATIVE ATTRIBUTES IN LABLAB BEAN (Lablab purpureus L.)
}

\author{
M. S. Raihan ${ }^{1}$ and M. A. Newaz \\ Department of Genetics and Plant Breeding \\ Bangladesh Agricultural University \\ Mymensingh 2202, Bangladesh
}

\begin{abstract}
General (GCA) and specific (SCA) combining ability for ten quantitative characters of seven parental genotypes and $21 \mathrm{~F}_{1} \mathrm{~s}$ derived from a $7 \times 7$ diallel cross without reciprocal was assessed. Combining ability analysis following Griffing's approaches suggested the association of both additive and non-additive gene action in the genetic system with the preponderance of additive gene effect in the expression of all the traits except number of inflorescences per plant. The non-additive genetic component was exclusive or predominant for inflorescence per plant. Ranking of the parents for ten characters on GCA performance indicated that the parental genotype DS-7 was the best general combiner for pollen sterility percent, 10-green pod weight, 20-seed weight and the genotype DS-27 for the trait pod yield per plant. The estimates of SCA effect revealed that in most of the cases, combinations of high $\mathrm{x}$ low or even low $\mathrm{x}$ low exhibited high SCA effect for many characters rather than high $\mathrm{x}$ high cross combinations indicating the importance of gene interaction. Based on SCA performances the crosses $S_{12} \times S_{11}$ and DS-164 $x$ DS-27 were the best specific combiners for days to $1^{\text {st }}$ flowering. The crosses DS-164 x S $\mathrm{S}_{12}$, DS-52 x S 11 , DS-164 $\mathrm{x}$ DS-9(t) were the best specific combinations for pollen sterility percent, pod length, and pod yield per plant respectively.
\end{abstract}

Key words: Lablab bean, combining ability, diallel cross, gene action

\section{INTRODUCTION}

Lablab bean (Lablab purpureus L.) is a major protein rich winter vegetable in Bangladesh. There is a great demand of both edible pods and mature dry seed for culinary uses among the people of Bangladesh. It is also regarded as income generating crop due to its wide spread cultivation. According to the latest statistics (BBS-2004) total bean production in Bangladesh was 149.86 thousand ton with an average yield of 4.82 ton per hectare during the year 2003-2004. The average yield of lablab bean in Bangladesh is very low in respect of the bean yield (10 ton/hectare) in global context. This low yield status is attributed due to the lack of prescribed production practices and lack of high potential varieties. Yield is a polygenic character resulting from the interaction of yield contributing characters influenced by environmental fluctuations. Selection is the important aspect of crop improvement programme but it is difficult to make improvement through direct

1 Department of Genetics and Plant Breeding, Bangabandhu Sheikh Mujibur Rahman Agricultural University, Gazipur-1706 
selection based on phenotypic performance as phenotypically superior performer not persist in subsequent generation. Therefore parents should be selected on the basis of their genetic value. Diallel analysis provides an effective means of obtaining rapid information about the genetic features of the homozygous lines. The main feature of diallel analysis is the combining ability (Sprague and Tatum, 1942). Selection of parents in terms of their ability to combine in hybrid combinations and subsequently use them for developing pure lines or hybrid varieties depends on their nature of combining ability i.e. GCA and SCA. The parent with higher GCA could be used for developing inbred variety while crosses showing higher SCA value could be used for developing hybrid variety. Assessment of combining ability will enable the breeders to choice properly the parental components to produce the best economic hybrids. Therefore, the present study as undertaken to find out he nature of gene action governing the expression of yield related characters and to assess the combining ability with a view to utilize the information in further breeding programmes.

\section{MATERIAL AND METHODS}

A $7 \times 7$ diallel cross without reciprocal was made during the winter season of 20032004, while the evaluation of $F_{1}$ s with parental genotypes was performed in the following winter season, 2004-2005. The field research was conducted at the experimental farm of the Department of Genetics and Plant Breeding, Bangladesh Agricultural University, Mymenshing. Seven genotypes of lablab bean viz. DS-164, DS-7, DS-9(t), DS-27, DS-52, two advanced strains $S_{11}$ (selection from cross DS-106 x DS -167) and $S_{12}$ (selection from cross DS-52 x DS-167) and their $21 \mathrm{~F}_{1} \mathrm{~s}$ derived from diallel cross were included in this experiment. The experiment was laid out in a Randomized Complete Block Design (RCBD) with 3 replications. The seedlings were raised in polybag first. Then they were transplanted into the pits of main field and three pits were assigned for one genotypes in a replication with interspaces of $3 \mathrm{~m}$. All the agronomic and plant protection measures were kept equal for the entire experiment. Data on ten yield related characters from each family of the $\mathrm{F}_{1}$ diallel population covering each replication were recorded and the primary statistical analysis of the data was done according to Snedecor and Cochran, 1967; Clark, 1973. Griffing's (1956) method 2, model 1 (fixed model) was used to study combining ability.

For each character GCA (for each parental component) and SCA (for each hybrid) were evaluated. Ratio of GCA/SCA sum of squares was computed to estimate the relative importance of GCA and SCA for all the characters. Ratio of GCA/SCA sum of square=1, means that the additive and non-additive effects are equally important; GCA $>$ SCA indicating greater importance of additive effect; GCA $<$ SCA indicating greater importance of non-additive effect.

\section{RESULTS AND DISCUSSION}

The analysis of variances for combining ability showed that both gca and sca variances were highly significant $(\mathrm{P}<0.001)$ for all the characters under study (Table 1). Moreover the gca : sca ratio was more than one for all the characters except inflorescences/plant (no.) indicating that all the characters were predominantly under additive genetic control. The results agree with the findings of Singh and Singh (1981), Singh et al. (1986) and Kabir and Sen (1990). 
Table 1. Analysis of variance (MS) of combining ability for different plant characters in a $7 \times 7$ diallel cross of lablab bean

\begin{tabular}{|c|c|c|c|c|c|c|c|c|c|c|c|}
\hline Item & $\mathrm{df}$ & $\begin{array}{l}\text { Days to } 1^{\text {st }} \\
\text { flowering }\end{array}$ & $\begin{array}{c}\text { Inflorescences/ } \\
\text { plant (no.) }\end{array}$ & $\begin{array}{c}\text { Flowers } \\
\text { /infloresce } \\
\text { nce (no.) }\end{array}$ & $\begin{array}{l}\text { Pollen } \\
\text { sterility } \\
\text { percent }\end{array}$ & $\begin{array}{c}\text { Pods/ } \\
\text { inflorescenc } \\
\text { e (no.) }\end{array}$ & $\begin{array}{l}\text { Pod length } \\
\quad(\mathrm{cm})\end{array}$ & $\begin{array}{l}\text { Pod width } \\
\quad(\mathrm{cm})\end{array}$ & $\begin{array}{l}\text { 10-green } \\
\text { pod wt }(\mathrm{g})\end{array}$ & $\begin{array}{c}20 \text {-seed wt. } \\
\text { (g) }\end{array}$ & $\begin{array}{c}\text { Pod } \\
\text { yield/plant } \\
(\mathrm{kg})\end{array}$ \\
\hline gca & 6 & $1314.90 * *$ & $271.16^{* * * *}$ & $40.54 * * *$ & 2.576 **** & 1.691 **** & $5.428 * * *$ & $0.169 * * *$ & $1401.07 * *$ & $24.85 * * *$ & $2.590 * * *$ \\
\hline sca & 21 & $130.45^{* * * *}$ & $349.15 * * *$ & $18.70 * * *$ & $1.534 * * *$ & $0.895 * * *$ & $1.444 * * *$ & $0.039 * * *$ & $94.43 * * *$ & $0.627 * * *$ & $2.120 * * *$ \\
\hline Error & 54 & 4.390 & 0.508 & 0.350 & 0.418 & 0.139 & 0.009 & 0.00033 & 0.385 & 0.197 & 0.003 \\
\hline gca:sca & & $10.08: 1$ & $0.77: 1$ & $2.16: 1$ & $1.68: 1$ & $1.89: 1$ & $1.68: 1$ & $4.38: 1$ & $14.8: 1$ & $39.6: 1$ & $1.22: 1$ \\
\hline
\end{tabular}

Table 2. Estimates of general combining ability (gca) effects for different plant characters in a $7 \times 7$ diallel cross of lablab bean

\begin{tabular}{|c|c|c|c|c|c|c|c|c|c|c|}
\hline Characters & $\begin{array}{l}\text { Days to } 1^{\text {st }} \\
\text { flowering }\end{array}$ & $\begin{array}{c}\text { Inflorescences/ } \\
\text { plant (no.) }\end{array}$ & $\begin{array}{c}\text { Flowers/ } \\
\text { inflorescence } \\
\text { (no.) }\end{array}$ & $\begin{array}{l}\text { Pollen } \\
\text { sterility } \\
\text { percent }\end{array}$ & $\begin{array}{c}\text { Pods/ } \\
\text { inflorescence } \\
\text { (no.) }\end{array}$ & $\begin{array}{l}\text { Pod length } \\
(\mathrm{cm})\end{array}$ & $\begin{array}{l}\text { Pod width } \\
\text { (cm) }\end{array}$ & $\begin{array}{l}\text { 10-green pod } \\
\text { wt. (no.) }\end{array}$ & $\begin{array}{l}\text { 20-seed wt. } \\
\text { (g) }\end{array}$ & $\begin{array}{l}\text { Pod yield/ } \\
\text { plant }(\mathrm{kg})\end{array}$ \\
\hline DS-164 & $5.45^{* * * *}$ & $8.767 * * *$ & $-2.950 * * *$ & 0.177 & $0.268^{*}$ & $-.332 * * *$ & $-0.012 *$ & $-7.662 * * *$ & $-1.860 * * *$ & $0.487 * * *$ \\
\hline DS-9(t) & $6.58 * * *$ & $-2.660 * * *$ & -0.015 & 0.106 & $-0.486^{* * * *}$ & $-.212 * * *$ & -0.009 & $2.830 * * *$ & $1.408 * * *$ & $-0.350 * * *$ \\
\hline DS-7 & $11.19 * * *$ & $-8.631 * * *$ & $-0.886 * * *$ & $-0.986 * * *$ & 0.188 & -0.0002 & $0.119 * * *$ & $14.96 * * *$ & $1.751 * * *$ & $-0.127 * * *$ \\
\hline DS-27 & $5.58 * * *$ & $4.670 * * *$ & $1.509 * * *$ & $-0.559 * *$ & $0.254 *$ & $1.396^{* * * *}$ & $-0.273 * * *$ & $6.181 * * *$ & $-0.601 * * *$ & 0.641 *** \\
\hline DS-52 & $5.95^{* * *}$ & $0.628^{* *}$ & $-1.051^{* * *}$ & -0.107 & -0.056 & $0.459 * * *$ & $0.022 * * *$ & 12.91 *** & $1.592 * * *$ & $0.435 * * *$ \\
\hline $\mathrm{S}_{11}$ & $-19.80 * * *$ & $-2.12 * * *$ & $1.047 * * *$ & $0.469 *$ & $0.629 * * *$ & $1.047 * * *$ & -0.002 & $-17.06^{* * *}$ & $-2.267 * * *$ & $-0.250 * * *$ \\
\hline $\mathrm{S}_{12}$ & $-15.57 * * *$ & $-0.691 * *$ & $2.450 * * *$ & $0.910 * * *$ & $-0.799 * * *$ & -0.039 & $0.156 * * *$ & $-12.15^{* * *}$ & -0.043 & $-8.400 * * *$ \\
\hline $\mathrm{SE}( \pm)$ & 0.647 & 0.219 & 0.183 & 0.199 & 0.115 & 0.029 & 0.006 & 0.191 & 0.137 & 0.017 \\
\hline
\end{tabular}


Table 3. Estimates of specific combining ability (sca) effects for different plant characters in a $7 \times 7$ diallel cross of lablab bean

\begin{tabular}{|c|c|c|c|c|c|c|c|c|c|c|}
\hline Characters & $\begin{array}{c}\text { Days to } \\
1^{\text {st }} \\
\text { flowering }\end{array}$ & $\begin{array}{c}\text { Inflorescences/ } \\
\text { plant (no.) }\end{array}$ & $\begin{array}{c}\text { Flowers/ } \\
\text { inflorescence } \\
\text { (no.) }\end{array}$ & $\begin{array}{c}\text { Pollen } \\
\text { sterility } \\
\text { percent }\end{array}$ & $\begin{array}{c}\text { Pods/ } \\
\text { inflorescence } \\
\text { (no.) }\end{array}$ & $\begin{array}{l}\text { Pod length } \\
\quad(\mathrm{cm})\end{array}$ & $\begin{array}{l}\text { Pod width } \\
\text { (cm) }\end{array}$ & $\begin{array}{l}\text { 10-green } \\
\text { pod wt. } \\
\text { (no.) }\end{array}$ & $\begin{array}{l}20 \text {-seed wt. } \\
\text { (g) }\end{array}$ & $\begin{array}{l}\text { Pod yield/ } \\
\text { plant }(\mathrm{kg})\end{array}$ \\
\hline DS-164 × DS-9(t) & $-4.247 *$ & $21.87 * * *$ & 0.418 & $1.716^{* *}$ & $0.808 * *$ & 0.011 & 0.256 *** & $5.257 * * *$ & 0.221 & $2.470^{* * *}$ \\
\hline DS-164 ×DS-7 & 2.431 & $-16.16^{* * *}$ & $5.006^{* * *}$ & 0.406 & 0.155 & $0.525 * * *$ & $0.226 * * *$ & $-8.969 * * *$ & 0.079 & $-1.311 * * *$ \\
\hline Ds-164 ×DS-27 & $-8.240 * * *$ & $-6.130 * * *$ & $-3.512 * * *$ & 0.547 & -0.294 & $-0.932 * * *$ & $0.330 * * *$ & $-2.810 * * *$ & 0.194 & $-0.620 * * *$ \\
\hline DS-164 ×DS-52 & $-7.281 * * *$ & $-3.25 * * *$ & $2.891 * * *$ & -0.212 & $0.944 * *$ & $-0.179 *$ & $0.325 * * *$ & $5.902 * * *$ & -0.328 & $0.850^{* * * *}$ \\
\hline DS-164 $\times \mathrm{S}_{12}$ & $8.025 * * *$ & $23.89 * * *$ & -0.377 & $-2.483 * * *$ & 0.058 & $0.294 * * *$ & $0.335^{* * * *}$ & $6.420 * * *$ & 0.173 & $1.521 * * *$ \\
\hline DS-164 $\times \mathrm{S}_{11}$ & $13.52 * * *$ & $6.991 * * *$ & $-2.427 * * *$ & -0.351 & $-0.853 * *$ & $-0.276^{* * *}$ & $0.477 * * *$ & $5.657 * * *$ & -0.102 & -0.063 \\
\hline DS- $9(\mathrm{t}) \times \mathrm{DS}-7$ & $-7.809 * * *$ & $7.280^{* * * *}$ & $-3.342 * * *$ & $1.848 * * *$ & -0.201 & $-0.393 * * *$ & $-0.136^{* * *}$ & $-6.809 * * *$ & $-0.756 *$ & $0.211 * * *$ \\
\hline DS-9 $(\mathrm{t}) \times$ DS-27 & -2.643 & $-9.031 * * *$ & $3.075 * * *$ & 0.391 & 0.183 & $0.720 * * *$ & $0.118 * * *$ & $12.24 * * *$ & $-0.972 * *$ & $-0.190 * * *$ \\
\hline DS-9(t) $\times$ DS-52 & $-6.081 * * *$ & $-14.33 * * *$ & $-3.934 * * *$ & -0.312 & $-0.873 * *$ & $-0.586^{* * *}$ & $0.107 * * *$ & $-8.143 * * *$ & -0.197 & $-1.800 * * *$ \\
\hline DS- $9(\mathrm{t}) \times \mathrm{S}_{12}$ & $11.45^{* * * *}$ & $3.660 * * *$ & $1.511^{* *}$ & 0.279 & -0.193 & $0.626 * * *$ & $0.116 * * *$ & $11.38^{* * * *}$ & $1.037 * *$ & $0.278 * * *$ \\
\hline DS- $9(t) \times S_{11}$ & $10.16^{* * *}$ & $12.10 * * *$ & $-2.335 * * *$ & -0.967 & 0.555 & $0.227 * *$ & $0.111^{* * * *}$ & $2.494 * * *$ & $0.794 *$ & $1.201 * * *$ \\
\hline DS-7 $\times$ DS- 27 & $3.474 *$ & $-12.89 * * *$ & $6.622 * * *$ & 0.066 & -0.330 & $-0.301 * * *$ & $0.255^{* * * *}$ & $8.221 * * *$ & -0.048 & $-0.950 * * *$ \\
\hline DS-7 $\times$ DS- 52 & $-4.030^{*}$ & $-1.950 * * *$ & $-1.706^{* * *}$ & 0.254 & $0.689 *$ & $-0.204 * *$ & $-0.030 *$ & $-7.606^{* * *}$ & -0.007 & $0.424 * * *$ \\
\hline DS- $7 \times \mathrm{S}_{12}$ & $13.96 * * *$ & $-5.701 * * *$ & $-7.571 * * *$ & -0.883 & -0.343 & $-0.396^{* * *}$ & 0.008 & $5.791 * * *$ & $1.261 * * *$ & $-0.119 *$ \\
\hline DS-7 $\times S_{11}$ & $6.905 * * *$ & $29.06 * * *$ & $-1.295 * *$ & $-1.315^{*}$ & 0.439 & $0.368 * * *$ & $0.280 * * *$ & $6.078 * * *$ & 0.285 & $2.220 * * *$ \\
\hline DS- $27 \times$ DS-52 & $-3.961^{*}$ & $-4.650 * * *$ & $6.901 * * *$ & 0.061 & $1.783 * * *$ & $0.601 * * *$ & $-0.112 * * *$ & $3.161 * * *$ & -0.588 & $1.270 * * *$ \\
\hline DS- $27 \times S_{12}$ & $13.89 * * *$ & $34.16^{* * *}$ & $-9.370 * * *$ & -0.929 & $-0.712 *$ & $0.741 * * *$ & $0.130 * * *$ & $9.450 * * *$ & $0.846^{*}$ & $1.801 * * *$ \\
\hline DS-27 $\times S_{11}$ & $7.700 * * *$ & $13.60 * * *$ & $-1.054^{*}$ & -0.479 & $-0.808^{* *}$ & 0.061 & $0.215^{* * * *}$ & $21.64 * * *$ & -0.161 & $1.330 * * *$ \\
\hline DS $-52 \times S_{12}$ & $13.25 * * *$ & $21.36 * * *$ & 0.311 & -0.314 & $-1.360 * * *$ & $0.455 * * *$ & $0.174 * * *$ & $2.619 * * *$ & $0.754 *$ & $0.123 * *$ \\
\hline SD-52 $\times \mathrm{S}_{11}$ & $12.79 * * *$ & $12.46 * * *$ & $2.743 * * *$ & $-1.750 * * *$ & $-0.349^{*}$ & $1.289 * * *$ & 0.022 & $7.133 * * *$ & -0.454 & $0.910^{* * *}$ \\
\hline $\mathrm{S}_{12} \times \mathrm{S}_{11}$ & $-16.94 * * *$ & $-19.71 * * *$ & $8.928 * * *$ & $1.551 * *$ & $2.164 * * *$ & $0.178 *$ & $0.036^{*}$ & $13.37 * * *$ & 0.580 & $-0.280 * * *$ \\
\hline $\mathrm{SE}( \pm)$ & 1.600 & 0.544 & 0.452 & 0.494 & 0.285 & 0.074 & 0.0139 & 0.474 & 0.338 & 0.042 \\
\hline
\end{tabular}

$* \mathrm{P}<0.05, * * \mathrm{P}<0.01, * * * \mathrm{P}<0.001$ 


\section{General Combining Ability}

The estimates of gca effect showed that no single parent exhibited all of the desirable characters. The gca value suggested that the parent DS-7 was the best general combiner for maximum number of characters viz. pollen sterility percent, 10-green pod weight and 20-seed weight. Negative GCA is preferable for days to $1^{\text {st }}$ flowering because it indicates the general capacity of early parents to transmit their behaviour to progeny in cross combinations with other parents. The parental genotypes $S_{11}$ and $S_{12}$ were desirable for their negative gca effects and among them $S_{11}$ emerged as the best general combiner for early flowering. For the trait pollen sterility percent the parent DS-7 and DS-27 differed significantly from zero with regard to negative gca effect. These genotypes were thus treated as good general combiners for pollen sterility percent. Estimated gca effect for the trait number of inflorescences/plant revealed that DS-164 was the best one for general combining ability followed by the parent DS-27. The parents $S_{12}$ and DS-27 were the best combiners to improve the flower bearing behaviour due to their highest gca effect. The estimated gca effect for pods per inflorescence ranged from 0.779 to 0.629 and among the parent $S_{11}$ was found to be the best general combiner followed by the parent DS-164.

The parental genotypes DS-27, DS-52 and $\mathrm{S}_{11}$ were desirable for the trait pod length due to their significant positive gca effect. Among the parents, DS-27 was emerged as the best general combiner for pod length. Positive gca effect means good combining ability for broad pods and negative gca effect would reflect combining ability for narrow pods. The highest positive gca effect was obtained in $S_{12}$ followed by the parent DS-7 indicating that these two would be the best general combiners for the broadest pod whereas the genotypes DS-27 and DS-164 exhibited the hightest negative value, thus these two genotypes were designated as good general combiners for narrow pods. Out of seven parental genotypes four parents had positive gca effect indicating that they were good general combiners for 10green pod weight. Estimated gca effect for 20 -seed weight revealed that all the parents except $S_{12}$ had significant value with high significance level $(\mathrm{p}<0.001)$ and the parent DS-7 was the best general combiner for this trait. Both positive and negative gca effects were observed for the trait pod yield per plant and gca effect for all the parents were highly significant $(\mathrm{p}<0.001)$. The parent DS-27 displayed the highest gca value followed by DS-52 and DS-164 for pod yield per plant.

\section{Specific combining ability}

The estimates of sca effect revealed the importance of gene interaction for the characters studied. The recorded sca value for days to $1^{\text {st }}$ flowering ranged from -16.94 to 13.96. The crosses $S_{12} \times S_{11}$, DS-164 x DS-27, DS-164 x DS-52 and DS-9(t) x DS-7 were the best specific combinations due to their highest negative sca effect. The sca effect of the crosses DS-164 x $\mathrm{S}_{12}$, DS-7 $\times \mathrm{S}_{11}$, and DS-52 $\times \mathrm{S}_{11}$ were negative and significantly different from zero, thus considered as the best specific combinations for pollen sterility percent. The cross DS-27 x $\mathrm{S}_{12}$ was the best specific combiner for the trait number of inflorescences per plant. The crosses DS-7 x DS -27, DS-27 x DS-52 and $S_{12} \times S_{11}$ would be the best specific combiners for number of flowers per inflorescence due their highest sca effect.

The crosses $S_{12} \times S_{11}$ was the best specific combination for the trait number of pods per inflorescence followed by the crosses DS-27 x DS -52, DS-164 x DS-52 and DS-164 $x$ DS-9(t). Among the 21 cross combinations 5 crosses viz. DS-164 x DS-7, DS-9(t) x DS-27, DS-27 $\times$ DS-52, DS-27 $\times S_{12}$ and DS-52 $\times S_{11}$ were treated as the best specific combiners due 
to their highest sca effect for pod length. The crosses DS-9(t) x DS-7, DS-7 x DS-52 and DS-27 x DS-52 exhibited the highest negative sca effect of varying significance level $(p<0.05-0.001)$ suggesting good combination for narrow pods. The rest of the crosses expressed positive sca effect and the crosses DS-164 x $\mathrm{S}_{11}$, DS-164 $\times \mathrm{S}_{12}$ and DS-164 x DS27 displayed the highest positive sca values indicating that these would be the best specific combinations for broader bean.

The sca effect for all the cross combinations or $\mathrm{F}_{1}$ genotypes were highly significant $(\mathrm{p}<0.001)$ for the trait 10 -green pod weight. The crosses DS-27 $\times \mathrm{S}_{11}$ and DS164 $\mathrm{x}$ DS-7 were the best and worst specific combinations respectively for this trait. For 20-seed weight the crosses DS-9(t) $\times \mathrm{S}_{12}$ and DS-7 $\times \mathrm{S}_{12}$ performed the best result. The sca effect for pod yield per plant was significant for all of the crosses except DS-164 x $S_{11}$. The recorded sca value reveled that the crosses DS-164 x DS-9(t), DS-164 x $S_{12}$, DS-7 x $S_{11}$, DS-27 x DS-52 and DS-27 x $S_{11}$ were good specific combiners for pod yield per plant.

\section{REFERENCES}

BBS. 2004. Monthly Statistical Bulletin, October. Bangladesh Bureau of Statistics, Statistics Division, Ministry of Planning. Government of the Peoples Republic of Bangladesh. p. 57.

Clark, G. M. 1973. Statistics and Experimental Design. Edward Arnold, London.

Griffing, B. 1956. Concept of general and specific combining ability in relation to diallel crossing system. Aust. J. Bio. Sci., 6(4): 463-493.

Kabir, J. and Sen, S.K. 1990. Diallel analysis for combining ability in Dolichos bean (Lablab niger medik and Dolichos uniflours lam.). Tropical Agriculture. 67(2): 123-126.

Singh, S.P. and Singh, H.N. 1981. Gene system involved and their implication in breeding of lablab bean (Dolichos lablab L.). Zeitschrift fun pflanzenzuchtung. 87(3): 240-247.

Singh, S.P.; Singh, N.H. and Srivastava, J.P. 1986. Combining ability in lablab bean (Lablab purpureus L.sweet). Indian Agriculturist. 30(2): 147-152.

Snedecor, G.W. and Cochran, W. 1967. Statistical methods. Ames. Iowa State College Press.

Sprague, G.F. and Tatum, L.A. 1942. General versus specific combining ability in single crosses of corn. J. Amer. Soc. Agron., 34: 923-932. 